\title{
Antistaphylococcal effects of alcoholic extracts of Tetrapleura tetraptera (Schum and Thonn.) (Taub.) against multidrug methicillin resistant Staphylococcus aureus
}

\begin{tabular}{|c|c|}
\hline \multicolumn{2}{|c|}{$\begin{array}{l}\text { Authors: } \\
\text { Morenike O. Adeoye-Isijola }{ }^{1} \text { (D) } \\
\text { Kubendran K. Naidoo }^{2} \text { (D) } \\
\text { Roger M. Coopoosamy }{ }^{2} \text { (D) } \\
\text { Olufunmiso O. Olajuyigbe }\end{array}$} \\
\hline \multicolumn{2}{|c|}{$\begin{array}{l}\text { Affiliations: } \\
{ }^{1} \text { Department of Microbio } \\
\text { School of Science and } \\
\text { Technology, Babcock } \\
\text { University, Ilisan-Remo, } \\
\text { Nigeria }\end{array}$} \\
\hline \multicolumn{2}{|c|}{$\begin{array}{l}{ }^{2} \text { Department of Nature } \\
\text { Conservation, Faculty of } \\
\text { Natural Sciences, } \\
\text { Mangosuthu University of } \\
\text { Technology, Umlazi, Durban, } \\
\text { South Africa }\end{array}$} \\
\hline \multicolumn{2}{|c|}{$\begin{array}{l}\text { Corresponding author: } \\
\text { Olufunmis Olajuyigbe, } \\
\text { funmijuyigbe12@yahoo.com }\end{array}$} \\
\hline \multicolumn{2}{|c|}{$\begin{array}{l}\text { Dates: } \\
\text { Received: } 10 \text { May } 2021 \\
\text { Accepted: } 07 \text { Aug. } 2021 \\
\text { Published: } 12 \text { Jan. } 2022\end{array}$} \\
\hline \multicolumn{2}{|c|}{$\begin{array}{l}\text { How to cite this article: } \\
\text { Adeoye-Isijola, M.O., Naidoo, } \\
\text { K.K., Coopoosamy, R.M. \& } \\
\text { Olajuyigbe, O.O., 2022, } \\
\text { 'Antistaphylococcal effects of } \\
\text { alcoholic extracts of } \\
\text { Tetrapleura tetraptera } \\
\text { (Schum and Thonn.) (Taub.) } \\
\text { against multidrug methicillin } \\
\text { resistant Staphylococcus } \\
\text { aureus', Journal of Medicinal } \\
\text { Plants for Economic } \\
\text { Development 6(1), a122. } \\
\text { https://doi.org/10.4102/ } \\
\text { jomped.v6i1.122 }\end{array}$} \\
\hline \multicolumn{2}{|c|}{$\begin{array}{l}\text { Copyright: } \\
\text { (C) 2022. The Authors. } \\
\text { Licensee: AOSIS. This work } \\
\text { is licensed under the } \\
\text { Creative Commons } \\
\text { Attribution License. }\end{array}$} \\
\hline Read online: & \\
\hline 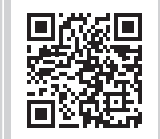 & $\begin{array}{l}\text { Scan this QR } \\
\text { code with your } \\
\text { smart phone or } \\
\text { mobile device } \\
\text { to read online. }\end{array}$ \\
\hline
\end{tabular}

Background: Staphylococcus aureus is a pathogen causing life-threatening hospital and communityacquired infections with high morbidity and mortality rates requiring constant vigilance.

Aim: This study aimed at investigating the antistaphylococcal effects of Tetrapleura tetraptera against different strains of multidrug methicillin resistant S. aureus (MRSA) to indicate the need for its use in ethnomedicine in addition to its fruits being used in traditional medicine.

Methods: In this study, the susceptibilities of S. aureus were investigated using multi-disc antibiotics and extracts of $T$. tetraptera by agar diffusion and macrobroth dilution methods.

Settings: While attention has been focused on the fruits of this plant, it is necessary to investigate the pharmacological importance of its stem bark.

Results: The antibiogram showed that $70 \%$ of the isolates were multidrug resistant. Nitrofurantoin and gentamicin antibiotics were the most effective whilst amoxicillin and augumentin were the least effective. The susceptibility of the isolates was concentration dependent as inhibition zones decreased with decrease in the concentrations of each of the extracts. The minimum inhibitory concentrations (MICs) of acetone extract ranged between $0.019 \mathrm{mg} / \mathrm{mL}$ and $20 \mathrm{mg} / \mathrm{mL}$ whilst the minimum bactericidal concentrations (MBCs) ranged between $0.3125 \mathrm{mg} / \mathrm{mL}$ and $20 \mathrm{mg} / \mathrm{mL}$. The MICs of the methanol extract ranged between $0.039 \mathrm{mg} / \mathrm{mL}$ and $5.0 \mathrm{mg} / \mathrm{mL}$ whilst the MBCs ranged between $0.3125 \mathrm{mg} / \mathrm{mL}$ and $10 \mathrm{mg} /$ $\mathrm{mL}$. Both extracts were more bactericidal than being bacteriostatic against all the isolates. The methanol extract was more active than the acetone extract as indicated by the varied inhibition zones and MICs obtained from the different extracts.

Conclusion: This study revealed the great therapeutic potentials of T. tetraptera and validated its use in ethnomedicine and would be effective in the treatment of multidrug and MRSA infections.

Keywords: antistaphylococcal activities; macrobroth dilution assay; methicillin resistant bacteria; nosocomial infections; pharmacological activity; Tetrapleura tetraptera.

\section{Introduction}

Staphylococcus aureus is one of the most prevalent Gram-positive cocci found as transient normal floral of human skin and mucosal surfaces in 20\% - 90\% of human population (Falugi et al. 2013). As an established cause of superficial and deep life-threatening infections (Moreillon, Que \& Glauser 2005), it is also an opportunistic pathogen causing skin lesions, abscesses, endocarditis, septicaemia, post-operative wound infections, nosocomial bacteraemia and toxic shock syndrome (Grothe et al. 2009) because of production of enzymes, toxins and release of multiple redundant virulence factors (Lacey, Geoghegan \& McLoughlin 2016). Although a leading cause of hospital and community-acquired infections are associated with high morbidity and mortality rates, the high mortality rate of $6.0 \%-46.5 \%$ because of S. aureus infections (Nickerson et al. 2009) has made this pathogen an important subject of constant vigilance.

As a result of global abuse and misuse of antibiotics used in treating human infections, resistance of pathogenic microorganisms to commonly used antibiotics has become a worldwide problem (Khorvash et al. 2012). In several African countries, methicillin resistant S. aureus (MRSA) became a major problem (Ahmed et al. 2012). Globally, MRSA infections have emerged as a major public health problem and a leading cause of nosocomial infections (Zhang 2001) and community-based infections such as soft tissue infections, septic arthritis, bacteraemia, toxic shock syndrome, necrotising fasciitis and necrotising pneumonia (Gillet et al. 2002). Although MRSA has become an endemic pathogen worldwide and exhibits multidrug resistance especially to both quinolones 
and aminoglycosides (Batt et al. 2015), accurate and quick identification of MRSA in clinical specimens are essential for timely decision on effective antimicrobial chemotherapy, especially through naturally derived phytochemicals or natural products.

Tetrapleura tetraptera (Fabaceae Family) is a medium-sized deciduous plant with fern-like foliage. It is a perennial plant that grows in the lowland forest along the Western Coast of Africa. The dried fruit has a pleasant aroma (Aladesanmi 2007) and is popularly used as a seasoning spice in Southern and Eastern Nigeria (Okwu 2003). It has many medicinal uses involving the uses of its leaves, fruit, bark and pod. The bark of this plant contains triterpenes (Note et al. 2009) with antiplasmodial activity (Lekana-Douki et al. 2011). Aderibigbe et al. (2007) indicated that it has neuropharmacological activity whilst the fruits are used as antidiabetic and antiinflammatory agents (Ojewole 2005). From literature search, it was observed that much attention has been focused on the fruits of this plant because of its use as spices whilst little effort has been directed towards investigating the pharmacological importance of its stem bark. Thus, investigating the antibacterial activities of the stem bark of this plant will add more knowledge to its pharmacological relevance. This study, therefore, investigated the antistaphylococcal effects of acetone and methanol stem bark extracts of $T$. tetraptera against different strains of multidrug MRSA to indicate the need for its use in ethnomedicine in addition to its fruits being used in ethnomedicine.

\section{Materials and methods Collection of plant material}

The bark materials of T. tetraptera (Taub.) were collected from the plant growing within a rural settlement in Ogun State, Nigeria. The plant was authenticated ethnobotanically whilst voucher specimen was being prepared. The bark sample was air-dried at room temperature, pulverised with a milling machine and extracted as described by Olajuyigbe and Afolayan (2012). This study was carried out in the Department of Microbiology of our University.

\section{Test organisms and inocula preparation}

The bacteria used in this study included 18 clinical strains of $S$. aureus obtained from urinary tract infections and two typed strains including S. aureus (ATCC 6538 and NCTC 6571) used as control. Bacteriologically, each of the clinical strains of $S$. aureus was streaked on mannitol salt agar (MSA) and nutrient agar, which were incubated overnight at $37^{\circ} \mathrm{C}$ for $24 \mathrm{~h}-48 \mathrm{~h}$. The bacterial colonies were subjected to Gram staining, microscopic appearance, colony morphology and biochemical tests such as tube coagulase test according to standard protocols (Cheesbrough 2002, 2009). The inocula of the test $S$. aureus strains were prepared using the colony suspension method (EUCAST 2000). Colonies picked from 24-h-old cultures grown on nutrient agar were used to make suspensions of the test organisms in saline solution to give an optical density of approximately 0.1 at $600 \mathrm{~nm}$. The suspension was then diluted 1:100 by inoculating $9.9 \mathrm{~mL}$ of sterile nutrient broth with $100 \mu \mathrm{L}$ of the bacterial suspension and thoroughly agitated before being used.

\section{Antibiogram study to test the Staphylococcus aureus using multi-disc antibiotics}

The antibacterial activity was determined using agar diffusion assay technique according to the modified KirbyBauer diffusion technique by swabbing the Mueller-Hinton agar (MHA) (Lab M, UK) plates with the adjusted suspension of each of the test strains. Multi-discs (Abtek) containing different antibiotics including augmentin (Aug) (30 $\mu \mathrm{g})$,

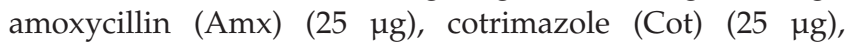
tetracycline (TET) $(10 \mu \mathrm{g})$, gentamicin (Gen) $(10 \mu \mathrm{g})$, ofloxacin (OFL) $(5 \mu \mathrm{g})$, nalidixic acid (Nal) $(30 \mu \mathrm{g})$ and nitrofurantoin (Nit) $(200 \mu \mathrm{g})$ were aseptically placed on the inoculated agar plates before being incubated at $37^{\circ} \mathrm{C}$ for $24 \mathrm{~h}$. After $24 \mathrm{~h}$ of incubation, the plates were examined for inhibition zones (Bauer et al. 1966). The diameter of the inhibition zones produced by each antibiotic disk were measured to the nearest millimetre and recorded.

\section{Antibacterial assay by agar diffusion (inhibition zones) methods}

For the initial determination of the antibacterial activities of the crude acetone and methanol extracts of T. tetraptera, the susceptibility screening of the test strains to the extracts was determined using the modified Kirby-Bauer diffusion technique involving swabbing sterile MHA (Lab M Ltd., Quest Park, UK) plates with the resultant saline suspension of each adjusted strain of $S$. aureus. Different concentrations of each of the extracts were prepared by dissolving known weights of the extracts in the extracting solvents. Wells, later filled with $100 \mu \mathrm{L}$ of different concentrations ( $\mathrm{C} 1=20 \mathrm{mg}$ / $\mathrm{mL}, \mathrm{C} 2=40 \mathrm{mg} / \mathrm{mL}, \mathrm{C} 3=60 \mathrm{mg} / \mathrm{mL}, \mathrm{C} 4=80 \mathrm{mg} / \mathrm{mL}$ and $\mathrm{C} 5=100 \mathrm{mg} / \mathrm{mL}$ ) of each of the extracts taking care not to allow spillage of the extracts onto the agar surface, were bored into the agar medium with a heat sterilised 6-mm-cork borer. The culture plates were allowed to stand on the laboratory bench for $1 \mathrm{~h}$ to allow proper diffusion of these solutions before incubating at $37^{\circ} \mathrm{C}$ for $24 \mathrm{~h}$. Wells in blank MHA containing $5 \%$ of each of the extracting solvents representing the final concentration in the test plates without the extract served as positive control. The determinations were performed in duplicates. After $24 \mathrm{~h}$ of incubation, the plates were examined for the presence of inhibition zones. Whilst the diameters of the inhibition zones produced by each concentration of each of the extracts were measured in millimetres (Clinical and Laboratory Standard Institute [CLSI] 2007) and interpreted using the CLSI zone diameter interpretative standards (CLSI 2008), the break point with an inhibition zone of diameter $\geq 11$ was chosen for bacterial susceptibility to the plant extracts (Nyenje \& Ndip 2011).

\section{Macrobroth dilution for determining minimum inhibitory concentration}

Minimum inhibitory concentration (MIC) defined as the lowest concentration, which resulted in maintenance or 
reduction of inoculums' viability was determined by macrobroth tube dilution technique for the $S$. aureus strains. Different concentrations ranging from $0.0048 \mathrm{mg} / \mathrm{mL}$ to $20 \mathrm{mg} / \mathrm{mL}$ of each of the crude extract were prepared by serial dilutions in double strength Mueller-Hinton broth. Each tube was then inoculated with $100 \mu \mathrm{L}$ of each of the adjusted strains. Two blank Mueller-Hinton broth tubes, with and without bacterial inoculation, were used as the growth and sterility controls. Assays were carried out in duplicate. The bacteria containing tubes were incubated at $37^{\circ} \mathrm{C}$ for $24 \mathrm{~h}$. The first tubes in the series with no visible growth after the incubation period were taken as the MICs.

\section{Determination of minimum bactericidal concentrations}

As the clinical occurrences of tolerance usually necessitate bactericidal testing, the minimum bactericidal concentration (MBC) was determined by sampling all the macroscopically clear tubes and the first turbid tube in the MIC series. Before being sampled, the tubes were gently mixed by flushing them with a sterile pipette and a $100 \mu \mathrm{L}$ aliquot was removed. Each aliquot was placed on a single antibiotic-free nutrient agar plate in a single streak down the centre of the plate in accordance with the method of Shanholtzer et al. (1984). The samples were allowed to be absorbed into the agar until the plate surface appeared dry (after $30 \mathrm{~min}$ ). The aliquot was then spread over the plate by making a lawn of the bacterial culture with sterile cotton swab. In many studies on microbial susceptibility, this subculturing method has been found satisfactory in eliminating the problem of antimicrobial agent carryover from the $100 \mu \mathrm{L}$ subcultured volume (Fasching et al. 1990). The growth and sterility controls were sampled in the same manner. The MBC determining lawned plates were incubated for $24 \mathrm{~h}$ at $37^{\circ} \mathrm{C}$. After the incubation periods, the lowest concentrations of the extract that did not produce any bacterial growth on the solid medium were regarded as the MBC values for each of these crude extracts. This observation was matched with the MIC test tube that did not show evidence of growth after $48 \mathrm{~h}$ of incubation.

\section{Determination of mechanisms of antibiosis (bactericidal or bacteriostatic)}

The mechanism of antibiosis of the extracts was calculated using the ratio of $\mathrm{MBC} / \mathrm{MIC}$ or $\mathrm{MIC}_{\text {index }}$ as described by Shanmughapriya et al. (2008) to elucidate whether the observed antibacterial effects were bactericidal or bacteriostatic. When the ratio of $\mathrm{MBC} / \mathrm{MIC}$ was $\leq 2.0$, the extract was considered bactericidal or otherwise bacteriostatic. If the ratio is $\geq 16.0$, the extract was considered ineffective.

\section{Statistical analysis}

Data expressed as mean \pm standard deviation (SD) of results obtained from duplicate determinations were analysed using Statistical Programme for Social Sciences (SPSS) V.16 (Statistical Programme for Social Sciences, SPSS Corporation, Chicago, IL). One way analysis of variance (ANOVA) were used to determine the differences amongst the mean and $p<$ 0.05 were regarded to be significant.

\section{Results}

In this study, the susceptibility of different strains of S. aureus was investigated using multi-disc antibiotics and different extracts of $T$. tetraptera by agar diffusion assay whilst the degree of the antibacterial activities of the extracts was determined by macrobroth dilution methods. From the susceptibility studies using multi-disc antibiotics, $70 \%$ of the isolates exhibited multidrug resistance whilst they exhibited varied degree of susceptibility to different antibiotics used. For all the isolates, Nit and Gen inhibited the highest number of isolates with inhibition zones of 20-37 $\pm 1.0 \mathrm{~mm}$ for Nit and between 15 and $33 \pm 1.0 \mathrm{~mm}$ for Gen. Nit and Gen both inhibited 13 of the isolates. Whilst TET inhibited 12 isolates with inhibition zones between 13 and $40 \pm 1.0 \mathrm{~mm}$ and cotrimoxazole inhibited 11 isolates with inhibition zones between 18 and $40 \pm 1.0 \mathrm{~mm}$. Ofloxacin inhibited 10 of the isolates and had inhibition zones ranging between 20 and $46 \pm 1.0 \mathrm{~mm}$, Nal inhibited eight isolates with inhibition zones between 24 and $34 \pm 1.0 \mathrm{~mm}$ and amoxicillin inhibited two isolates and augumentin inhibited one of these two isolates to produce higher inhibition zone of $28 \mathrm{~mm} \pm 1.0 \mathrm{~mm}$ against $16 \mathrm{~mm} \pm 1.0 \mathrm{~mm}$ produced by amoxicillin as shown in Table 1.

The susceptibility of the different strains of $S$. aureus, used in this study, to the two extracts of T. tetraptera is presented in Table 2. The susceptibility of the isolates was concentration dependent as it decreased with decrease in the concentrations of each of the extracts. A total of $100 \mu \mathrm{L}$ of different concentrations of each of the extracts produced varied degree of inhibition zones. At the lowest concentration of $20 \mathrm{mg} / \mathrm{mL}$ of acetone extract, $100 \mu \mathrm{L}$ produced inhibition zones that ranged between $12 \mathrm{~mm} \pm 1.0 \mathrm{~mm}$ and $18 \mathrm{~mm} \pm 1.0 \mathrm{~mm}$. At the highest concentration of $100 \mathrm{mg} / \mathrm{mL}$ of this extract, $100 \mu \mathrm{L}$ produced inhibition zones that ranged between $17 \mathrm{~mm} \pm$ $1.0 \mathrm{~mm}$ and $25 \mathrm{~mm} \pm 1.0 \mathrm{~mm}$. At the lowest concentration of $20 \mathrm{mg} / \mathrm{mL}$ of the methanol extract, $100 \mu \mathrm{L}$ produced inhibition zones that ranged between $13 \mathrm{~mm} \pm 1.0 \mathrm{~mm}$ and $20 \mathrm{~mm} \pm$ $1.0 \mathrm{~mm}$. At the highest concentration $(100 \mathrm{mg} / \mathrm{mL})$ of this extract, the inhibition zones ranged between $18 \mathrm{~mm} \pm 1.0 \mathrm{~mm}$ and $26 \mathrm{~mm} \pm 1.0 \mathrm{~mm}$. Other concentrations in between the highest and the lowest concentrations also produced varied sizes of the inhibition zones.

The degrees of the antibacterial activities of T. tetrapleura against the clinical isolates of $S$. aureus as determined by the macrobroth dilution assay are presented in Table 3 . The MICs of the acetone extract ranged between $0.019 \mathrm{mg} / \mathrm{mL}$ and $20 \mathrm{mg} / \mathrm{mL}$ whilst the $\mathrm{MBC}$ ranged between $0.3125 \mathrm{mg} / \mathrm{mL}$ and $20 \mathrm{mg} / \mathrm{mL}$. Eight of the isolates had their MICs at concentrations less than $1 \mathrm{mg} / \mathrm{mL}$. Three of the isolates had their MICs at concentrations equal to $1.25 \mathrm{mg} / \mathrm{mL}$ whilst the rest of the isolates had their MICs at concentrations greater than $2 \mathrm{mg} / \mathrm{mL}$. Although it was 
bacteriostatic against eight of the isolates, $\mathrm{MIC}_{\text {index }}$ showed that the extract was bactericidal against more of the isolates. For two of the isolates, SA13 and SA16, having their MBCs equal to $0.3125 \mathrm{mg} / \mathrm{mL}$, the MBCs of the acetone extract were $>1 \mathrm{mg} / \mathrm{mL}$.

Considering the antibacterial activities of the methanol extract, this extract inhibited all the isolates at concentrations ranging between $0.039 \mathrm{mg} / \mathrm{mL}$ and $5.0 \mathrm{mg} / \mathrm{mL}$ whilst the
MBCs, generally, ranged between $0.3125 \mathrm{mg} / \mathrm{mL}$ and $10 \mathrm{mg} / \mathrm{mL}$. Of the nine isolates that had their MICs at concentrations $<1 \mathrm{mg} / \mathrm{mL}$, six isolates had their MICs at $0.625 \mathrm{mg} / \mathrm{mL}$. With the exception of SA11 and SA14 having MBCs equal to $0.3125 \mathrm{mg} / \mathrm{mL}$ and those of SA1 and SA15 being $0.625 \mathrm{mg} / \mathrm{mL}$, the $\mathrm{MBCs}$ of other isolates ranged between $1.25 \mathrm{mg} / \mathrm{mL}$ and $10 \mathrm{mg} / \mathrm{mL}$. Whilst the $\mathrm{MIC}_{\text {index }}$ indicated that the extract was ineffective against SA1 and SA2 and bacteriostatic against six isolates, both extracts were

TABLE 1: Antibiotics resistance profile of different strains of Staphylococcus aureus as determined by disc diffusion assay using different antibiotic discs.

\begin{tabular}{|c|c|c|c|c|c|c|c|c|}
\hline \multirow[t]{2}{*}{ Test Staphylococcus strains } & \multicolumn{8}{|c|}{ Inhibition zones produced by different antibiotics $( \pm 1.0 \mathrm{~mm})$} \\
\hline & OFL $(5 \mu \mathrm{g})$ & AUG $(30 \mu \mathrm{g})$ & TET $(25 \mu \mathrm{g})$ & AMX $(25 \mu \mathrm{g})$ & СОТ (25 $\mu \mathrm{g})$ & NIT $(200 \mu g)$ & NAL $(30 \mu \mathrm{g})$ & GEN $(10 \mu \mathrm{g})$ \\
\hline SA 1 & $40(S)$ & $6(\mathrm{R})$ & $40(S)$ & $20(S)$ & $34(S)$ & $20(S)$ & $32(S)$ & $28(S)$ \\
\hline SA 3 & $29(S)$ & $6(\mathrm{R})$ & $6(\mathrm{R})$ & $6(\mathrm{R})$ & $26(S)$ & $20(S)$ & $28(S)$ & $6(\mathrm{R})$ \\
\hline SA 4 & $6(R)$ & $6(R)$ & $6(R)$ & $6(R)$ & $6(\mathrm{R})$ & $6(R)$ & $6(R)$ & $6(R)$ \\
\hline SA 5 & $6(R)$ & $6(R)$ & $16(S)$ & $6(\mathrm{R})$ & $6(\mathrm{R})$ & $28(S)$ & $6(R)$ & $18(S)$ \\
\hline SA 7 & $24(S)$ & $6(R)$ & $6(R)$ & $6(\mathrm{R})$ & $6(R)$ & $6(R)$ & $25(S)$ & $21(S)$ \\
\hline SA 8 & $6(R)$ & $6(R)$ & $6(R)$ & $6(R)$ & $6(\mathrm{R})$ & $6(R)$ & $6(R)$ & $6(R)$ \\
\hline SA 9 & $6(R)$ & $6(R)$ & $6(\mathrm{R})$ & $6(\mathrm{R})$ & $6(\mathrm{R})$ & $6(\mathrm{R})$ & $6(R)$ & $6(\mathrm{R})$ \\
\hline SA 10 & $35(\mathrm{~S})$ & $6(R)$ & $32(\mathrm{~S})$ & $6(\mathrm{R})$ & $18(\mathrm{~S})$ & $33(\mathrm{~S})$ & $24(S)$ & $23(\mathrm{~S})$ \\
\hline SA 11 & $29(S)$ & $6(R)$ & $32(S)$ & $6(R)$ & $23(S)$ & $25(S)$ & $30(S)$ & $22(S)$ \\
\hline SA 12 & $27(S)$ & $6(R)$ & $15(S)$ & $6(R)$ & $22(\mathrm{~S})$ & $30(S)$ & $6(R)$ & $32(\mathrm{~S})$ \\
\hline SA 14 & $29(S)$ & $6(R)$ & $32(\mathrm{~S})$ & $6(\mathrm{R})$ & $33(\mathrm{~S})$ & $23(S)$ & $24(S)$ & $27(S)$ \\
\hline SA 15 & $6(R)$ & $6(R)$ & $6(R)$ & $6(R)$ & $6(\mathrm{R})$ & $6(R)$ & $6(R)$ & $6(R)$ \\
\hline SA 16 & $6(R)$ & $6(R)$ & $13(I)$ & $6(\mathrm{R})$ & $18(\mathrm{~S})$ & $35(S)$ & $6(\mathrm{R})$ & $33(S)$ \\
\hline SA 17 & $6(R)$ & $6(R)$ & $14(1)$ & $6(\mathrm{R})$ & $20(S)$ & $37(S)$ & $6(R)$ & $33(S)$ \\
\hline SA 18 & $6(R)$ & $6(R)$ & $15(\mathrm{~S})$ & $6(\mathrm{R})$ & $6(\mathrm{R})$ & $30(\mathrm{~S})$ & $6(\mathrm{R})$ & $17(S)$ \\
\hline SA 19 ATCC 6538 & $25(S)$ & $6(R)$ & $34(S)$ & $6(\mathrm{R})$ & $23(S)$ & $25(S)$ & $6(R)$ & $6(\mathrm{R})$ \\
\hline SA 20 NCT 6571 & $6(R)$ & $6(R)$ & $16(S)$ & $6(\mathrm{R})$ & $6(\mathrm{R})$ & $30(\mathrm{~S})$ & $6(\mathrm{R})$ & $15(\mathrm{~S})$ \\
\hline
\end{tabular}

S, Staphylococcus aureus; OFL, Ofloxacin; AUG, Augmentin; TET, Tetracycline; AMX, Amoxicillin; COT, Cotrimazole; NIT, Nitrofurantoin; NAL, Nalidixic acid; GEN, Gentamicin; R, Resistant; S, Sensitive; I, Intermediate susceptible.

TABLE 2: Antistaphylococcal activities of Tetrapleura tetraptera against Staphylococcus aureus by agar diffusion assay.

\begin{tabular}{|c|c|c|c|c|c|c|c|c|c|c|}
\hline \multirow[t]{3}{*}{ Test Staphylococcus strains } & \multicolumn{10}{|c|}{ Average inhibition zones produced by $100 \mu \mathrm{L}$ of different concentrations of the extract $( \pm 1.0 \mathrm{~mm})$} \\
\hline & \multicolumn{5}{|c|}{ Acetone $(\mathrm{mg} / \mathrm{mL})$} & \multicolumn{5}{|c|}{ Methanol (mg/mL) } \\
\hline & $\mathrm{C5}=100$ & $\mathrm{C4}=80$ & $C 3=60$ & $C 2=40$ & $\mathrm{C} 1=\mathbf{2 0}$ & C5 $=100$ & $C 4=80$ & $C 3=60$ & $C 2=40$ & $\mathrm{C} 1=\mathbf{2 0}$ \\
\hline SA 1 & $22 \pm 1.23$ & $20 \pm 0.58$ & $18 \pm 1.23$ & $16 \pm 0.58$ & $15 \pm 1.00$ & $23 \pm 0.00$ & $20 \pm 0.58$ & $18 \pm 0.58$ & $16 \pm 1.23$ & $13 \pm 0.00$ \\
\hline SA 2 & $18 \pm 0.58$ & $17 \pm 0.00$ & $15 \pm 0.58$ & $15 \pm 0.00$ & $13 \pm 0.00$ & $20 \pm 0.58$ & $18 \pm 0.58$ & $17 \pm 0.00$ & $15 \pm 0.58$ & $13 \pm 0.00$ \\
\hline SA 3 & $18 \pm 1.00$ & $15 \pm 0.58$ & $13 \pm 0.58$ & $14 \pm 1.00$ & $13 \pm 0.00$ & $18 \pm 1.23$ & $15 \pm 0.00$ & $14 \pm 0.00$ & $13 \pm 0.00$ & $12 \pm 0.00$ \\
\hline SA 4 & $20 \pm 0.58$ & $18 \pm 0.58$ & $17 \pm 0.00$ & $15 \pm 0.00$ & $14 \pm 0.00$ & $22 \pm 0.58$ & $21 \pm 0.58$ & $19 \pm 0.58$ & $17 \pm 0.00$ & $15 \pm 0.58$ \\
\hline SA 5 & $22 \pm 0.58$ & $20 \pm 1.00$ & $18 \pm 0.00$ & $18 \pm 1.00$ & $16 \pm 0.58$ & $26 \pm 0.58$ & $23 \pm 0.58$ & $21 \pm 0.58$ & $20 \pm 0.58$ & $20 \pm 0.58$ \\
\hline SA 6 & $20 \pm 0.58$ & $17 \pm 0.00$ & $15 \pm 0.58$ & $14 \pm 0.00$ & $14 \pm 0.00$ & $22 \pm 0.58$ & $20 \pm 1.00$ & $17 \pm 0.00$ & $15 \pm 1.00$ & $14 \pm 1.00$ \\
\hline SA 7 & $19 \pm 1.00$ & $16 \pm 0.58$ & $15 \pm 1.23$ & $18 \pm 0.58$ & $13 \pm 0.58$ & $24 \pm 0.58$ & $21 \pm 0.58$ & $19 \pm 1.00$ & $17 \pm 1.23$ & $16 \pm 0.58$ \\
\hline SA 8 & $17 \pm 1.00$ & $16 \pm 0.00$ & $15 \pm 0.58$ & $15 \pm 0.58$ & $14 \pm 0.00$ & $22 \pm 0.58$ & $20 \pm 0.00$ & $17 \pm 0.58$ & $15 \pm 0.00$ & $12 \pm 0.00$ \\
\hline SA 9 & $18 \pm 0.00$ & $17 \pm 0.00$ & $15 \pm 0.00$ & $15 \pm 0.00$ & $13 \pm 0.00$ & $22 \pm 0.58$ & $20 \pm 0.00$ & $18 \pm 0.58$ & $15 \pm 0.58$ & $14 \pm 0.58$ \\
\hline SA 10 & $19 \pm 0.58$ & $16 \pm 0.58$ & $13 \pm 0.00$ & $18 \pm 0.00$ & $16 \pm 0.58$ & $18 \pm 0.00$ & $20 \pm 0.58$ & $18 \pm 0.00$ & $17 \pm 1.00$ & $15 \pm 0.00$ \\
\hline SA 11 & $21 \pm 0.58$ & $20 \pm 0.58$ & $18 \pm 0.58$ & $16 \pm 0.58$ & $15 \pm 0.00$ & $21 \pm 0.58$ & $18 \pm 0.58$ & $17 \pm 1.23$ & $15 \pm 0.58$ & $13 \pm 0.58$ \\
\hline SA 12 & $18 \pm 1.23$ & $18 \pm 1.00$ & $17 \pm 0.58$ & $16 \pm 0.58$ & $15 \pm 0.00$ & $19 \pm 0.00$ & $18 \pm 0.00$ & $19 \pm 0.58$ & $17 \pm 0.00$ & $15 \pm 0.00$ \\
\hline SA 13 & $20 \pm 1.00$ & $18 \pm 0.00$ & $16 \pm 0.00$ & $15 \pm 0.00$ & $14 \pm 0.00$ & $23 \pm 0.58$ & $23 \pm 0.00$ & $20 \pm 0.58$ & $18 \pm 0.58$ & $16 \pm 0.58$ \\
\hline SA 14 & $17 \pm 0.58$ & $15 \pm 0.58$ & $14 \pm 0.00$ & $13 \pm 0.00$ & $13 \pm 1.00$ & $21 \pm 0.58$ & $18 \pm 0.58$ & $17 \pm 0.00$ & $14 \pm 0.00$ & $12 \pm 0.00$ \\
\hline SA 15 & $20 \pm 0.58$ & $18 \pm 1.00$ & $17 \pm 0.58$ & $16 \pm 1.00$ & $14 \pm 0.58$ & $22 \pm 1.23$ & $20 \pm 0.00$ & $18 \pm 0.58$ & $16 \pm 0.00$ & $15 \pm 0.00$ \\
\hline SA 16 & $25 \pm 0.58$ & $23 \pm 0.00$ & $21 \pm 0.00$ & $20 \pm 0.58$ & $18 \pm 0.58$ & $26 \pm 1.00$ & $25 \pm 0.58$ & $23 \pm 0.58$ & $22 \pm 0.58$ & $20 \pm 0.00$ \\
\hline SA 17 & $25 \pm 0.58$ & $24 \pm 0.58$ & $20 \pm 0.58$ & $17 \pm 0.00$ & $15 \pm 0.00$ & $20 \pm 0.58$ & $18 \pm 0.58$ & $16 \pm 0.00$ & $15 \pm 0.00$ & $15 \pm 0.58$ \\
\hline SA 18 & $21 \pm 0.58$ & $20 \pm 0.58$ & $19 \pm 0.58$ & $17 \pm 0.00$ & $16 \pm 1.23$ & $22 \pm 0.58$ & $20 \pm 1.23$ & $19 \pm 0.58$ & $17 \pm 0.58$ & $15 \pm 0.00$ \\
\hline SA 19 ATCC 6538 & $15 \pm 0.00$ & $14 \pm 0.00$ & $15 \pm 0.00$ & $15 \pm 1.23$ & $12 \pm 0.00$ & $20 \pm 0.00$ & $18 \pm 0.58$ & $16 \pm 1.00$ & $15 \pm 0.00$ & $14 \pm 0.58$ \\
\hline SA 20 NCT 6571 & $21 \pm 0.58$ & $20 \pm 0.58$ & $18 \pm 1.00$ & $16 \pm 0.00$ & $13 \pm 0.00$ & $22 \pm 0.58$ & $21 \pm 0.00$ & $19 \pm 0.58$ & $17 \pm 0.00$ & $15 \pm 1.00$ \\
\hline
\end{tabular}

$\mathrm{SA}$, Staphylococcus aureus; $\mathrm{C} 1-\mathrm{C} 5$, different concentrations of the extracts. 
TABLE 3: Antistaphylococcal activities of Tetrapleura tetraptera against Staphylococcus aureus by macrobroth dilution assay.

\begin{tabular}{|c|c|c|c|c|c|c|c|c|}
\hline \multirow[t]{2}{*}{ Test Staphylococcus strains } & \multicolumn{4}{|c|}{ Acetone } & \multicolumn{4}{|c|}{ Methanol } \\
\hline & $\mathrm{MIC}(\mathrm{mg} / \mathrm{mL})$ & $\mathrm{MBC}(\mathrm{mg} / \mathrm{mL})$ & MIC $_{\text {index }}$ & Remarks & $\mathrm{MIC}(\mathrm{mg} / \mathrm{mL})$ & $\mathrm{MBC}(\mathrm{mg} / \mathrm{mL})$ & MIC $_{\text {index }}$ & Remarks \\
\hline SA 1 & 0.625 & 2.5 & 4 & B'static & 0.039 & 0.625 & 16 & Ineffective \\
\hline SA 2 & 2.5 & 2.5 & 1 & B'cidal & 0.625 & 10.0 & 16 & Ineffective \\
\hline SA 3 & 0.625 & 1.25 & 2 & B'cidal & 2.5 & 2.5 & 1 & B'cidal \\
\hline SA 4 & 20.0 & 20.0 & 1 & B'cidal & 5.0 & 5.0 & 1 & B'cidal \\
\hline SA 5 & 0.625 & 5.0 & 8 & B'static & 1.25 & 1.25 & 1 & B'cidal \\
\hline SA 6 & $>20.0$ & $>20.0$ & 1 & B'cidal & 5.0 & 10 & 2 & B'cidal \\
\hline SA 7 & 2.5 & 5.0 & 2 & B'cidal & 2.5 & 5.0 & 2 & B'cidal \\
\hline SA 8 & $>20.0$ & $>20.0$ & 1 & B'cidal & 5.0 & 10 & 2 & B'cidal \\
\hline SA 9 & $>20.0$ & $>20.0$ & 1 & B'cidal & 1.25 & 2.5 & 2 & B'cidal \\
\hline SA 10 & 2.5 & 5.0 & 2 & B'cidal & 2.5 & 10.0 & 4 & B'static \\
\hline SA 11 & 0.625 & 1.25 & 2 & B'cidal & 0.078 & 0.3125 & 4 & B'static \\
\hline SA 12 & 1.25 & 5.0 & 4 & B'static & 0.625 & 1.25 & 2 & B'cidal \\
\hline SA 13 & 0.019 & 0.3125 & 8 & B'static & 1.25 & 2.5 & 2 & B'cidal \\
\hline SA 14 & 1.25 & 5.0 & 4 & B'static & 0.019 & 0.3125 & 8 & B'static \\
\hline SA 15 & 2.5 & 20.0 & 8 & B'static & 0.625 & 0.625 & 1 & B'cidal \\
\hline SA 16 & 0.3125 & 0.3125 & 1 & B'cidal & 0.625 & 2.5 & 4 & B'static \\
\hline SA 17 & 0.156 & 1.25 & 8 & B'static & 0.625 & 2.5 & 4 & B'static \\
\hline SA 18 & 0.156 & 1.25 & 8 & B'static & 0.625 & 2.5 & 4 & B'static \\
\hline SA 19 ATCC 6538 & $>20.0$ & $>20.0$ & 1 & B'cidal & 5.0 & 5.0 & 1 & B'cidal \\
\hline SA 20 NCT 6571 & 1.25 & 2.5 & 2 & B'cidal & 5.0 & 10 & 2 & B'cidal \\
\hline
\end{tabular}

SA, Different strains of Staphylococcus aureus; B'static, Bacteriostatic; B'cidal, Bacteriocidal; MIC, Minimum inhibitory concentrations; MBC, Minimum bactericidal concentrations.

bactericidal against 12 different isolates. The methanol extract was more active than the acetone extract as indicated by the varied inhibition zones produced from the least to the highest concentrations and ranges of MICs obtained from the different extracts.

\section{Discussion}

To effectively decrease the usage of vancomycin and discover an alternative therapeutic agent for treating infections caused by MRSA, interest in traditional and nonconventional medical treatment has increased tremendously. As a result, mixed and severe infections have been treated effectively and emergence of resistant microorganisms have been prevented whilst attention has been focused simultaneously on discovering new antimicrobial compounds of plant origin (Ncube, Afolayan \& Okoh 2008). Eventually, natural products were regarded as interesting alternatives for the treatment of infections because they are rich in varieties of secondary metabolites with antimicrobial properties (Moglad 2021).

Although several studies have focused on the antibacterial activity of different plant extracts (Govindappa et al. 2011; Olajuyigbe \& Afolayan 2018) and acetone and methanol solvents have been referred to as junk extractor pulling out more phytoconstituents than other solvents (Eloff 1998), attention is rarely focused on the comparative analysis of their antibacterial or therapeutic potentials whilst some school of thought has indicated that these two solvents should not be used together in extraction because of the closeness in their polarity. However, this study, using a single bacterial species considered having similar intrinsic morphological and physiological features and exhibiting significant multidrug resistant patterns, has focused on comparing the antibacterial activity of the extracts of these two solvents to either justify their use as extractors or agree to the above-mentioned acclaimed reasoning.

In this study, the antibacterial potential of the acetone and methanol extracts of T. tetraptera was significant even though the varied sensitivity observed may be attributed to different resistance levels between the strains (Ahmad \& Aqil 2007). Whilst Rios and Recio (2005) suggested that MIC $>1 \mathrm{mg} / \mathrm{mL}$ of crude extracts should be disregarded and Simões, Bennett and Rosa (2009) reported that phytochemicals are routinely classified as antimicrobials when susceptibility tests had MICs in the range of $0.1 \mathrm{mg} / \mathrm{mL}-1.0 \mathrm{mg} / \mathrm{mL}$, Fabry, Okemo and Ansorg (1998) defined active crude extracts as those having MIC values $<8 \mathrm{mg} / \mathrm{mL}$. For acetone extract, eight of the isolates had MICs $<1 \mathrm{mg} / \mathrm{mL}$ and 15 of the isolates had MICs $<8 \mathrm{mg} / \mathrm{mL}$. For methanol extract, nine of the isolates had MICs $<1 \mathrm{mg} / \mathrm{mL}$ whilst MICs for all the isolates were $\leq 5 \mathrm{mg} / \mathrm{mL}$. Hence, as lower MIC and MBC values indicate higher efficacy (Cowan 1999), the extracts were considered effective bactericidal agents as indicated by their mechanisms of antibiosis or $\mathrm{MIC}_{\text {index }}$. By inference from data obtained, the methanol extract, in this study, was more effective and showed better antistaphylococcal activity than the acetone extract. The antistaphylococcal activity exhibited by the methanol extract may be attributed to the fact that more phytochemicals with higher therapeutic potentials may have been extracted by the methanol than what were extracted by the acetone. This is in agreement with the previously reported ethanol extract of $T$. tetraptera indicating MICs ranging between $0.0078 \mathrm{mg} / \mathrm{mL}$ and $10.0 \mathrm{mg} / \mathrm{mL}$ (Olajuyigbe \& Afolayan 2018). 
This study is in agreement with many studies that indicated that Gram-positive bacteria are often more inhibited by plant extracts than Gram-negative bacteria (Duraipandiyan \& Ayyanar 2006), that the Gram-positive multidrug and MRSA strains were susceptible to both extracts showed that the extracts were able to overcome the permeability barrier provided by the cell wall and the membrane accumulated resistance mechanisms including efflux of antibacterial agents (Kim et al. 2013). Considering that most of these isolates were multidrug resistant, the ability of the extracts to modulate and overcome resistance is implied by the degree of antibacterial activities exhibited by the two extracts as Aburjai et al. (2001) and Darwish et al. (2002) indicated that many plants are known for their action as a resistance-modifying agent. The MBC values appeared to be more reliable than the MIC values because it indicated that the extracts are bactericidal (Olajuyigbe \& Afolayan 2011) coupled with the resistance modulation effects of the extracts, however, further affirmed the tendency to achieve effective treatment of bacterial infection with these extracts when used against bacteria, which have become grossly resistant.

\section{Conclusion}

In conclusion, this study signified that methanol extract of the stem bark showed a better antibacterial activity at lower concentrations than the acetone extract and this may be attributed to the fact that methanol extracted more phytochemicals than the acetone. The present study indicated the potential effectiveness of this plant in the treatment of infections, which may involve multidrug MRSA and justify its use in ethnomedicine. This could help researchers to form the basis for selecting this plant species for isolating, identifying and comparing the bioactive constituents of these two extracts to justify the variation in the degree of the antibacterial activities of the plant.

\section{Acknowledgements Competing interests}

The authors declare that they have no financial or personal relationships that may have inappropriately influenced them in writing this article.

\section{Authors' contributions}

All authors contributed equally to this work.

\section{Ethical considerations}

This article followed all ethical standards for research without direct contact with human or animal subjects.

\section{Funding information}

This research received no specific grant from any funding agency in the public, commercial or no-for-profit sectors.

\section{Data availability}

Data created or analysed in this study were included in this manuscript.

\section{Disclaimer}

The views and opinions expressed in this article are those of the authors and do not necessarily reflect the official policy or position of any affiliated agency of the authors.

\section{References}

Aburjai, T., Darwish, R.M., Al-Khalil, S., Mahafza, A. \& Al-Abbadi, A., 2001, 'Screening of antibiotic resistant inhibitors from local plant materials against two different strains of Pseudomonas aeruginosa', Journal of Ethnopharmacology 76(1), 39-44. https://doi.org/10.1016/S0378-8741(01)00206-9

Aderibigbe, A.O., Iwalewa, E.O., Adesina, S.K., Ukponmwan, O.E. \& Adebanjo, A.O. 2007, 'Neuropharmaco-logical evaluation of Aridanin, A glycoside Isolated from Tetrapleura tetraptera Fruit', Discovery and Innovation 19(3), 177-181. https:// doi.org/10.4314/dai.v19i3.15799

Ahmad, I. \& Aqil, F., 2007, 'In vitro efficacy of bioactive extracts of 15 medicinal plants against ES $\beta$ L-producing multidrug resistant enteric bacteria', Microbiological Research 162(3), 264-275. https://doi.org/10.1016/j.micres.2006.06.010

Ahmed, M.O., Elramalli, A.K., Amri, S.G., Abuzweda, A.R. \& Abouzeed, Y.M., 2012, 'Isolation and screening of methicillin-resistant Staphylococcus aureus from health care workers in Libyan hospitals', Eastern Mediterranean Health Journa 18(1), 37-42. https://doi.org/10.26719/2012.18.1.37

Aladesanmi, A.J., 2007, 'Tetraplura tetraptera: Molluscicidal activity and chemical constituents', African Journal of Traditional Complementary and Alternative Medicine 4(1), 23-36. https://doi.org/10.4314/ajtcam.v4i1.31189

Batt, M.P., Bhalla, G.S., Tandel, K., Jindamwar, P., Chaudhari, C.N. \& Sahni, N.G.A.K., 2015, 'Antimicrobial susceptibility profile of methicillin-resistant Staphylococcus aureus at a tertiary care center', Archives of Clinical Microbiology 6(3), 6 .

Bauer, A.W., Kirby, W.M., Sherris, J.C. \& Truck, M., 1966, 'Antibiotic susceptibility testing by a standardized single disk method', American Journal of Clinical Pathology 45(4), 493-496. https://doi.org/10.1093/ajcp/45.4_ts.493

Cheesbrough, M., 2002, 'Medical laboratory manual for tropical countries', in ELBS (ed.), pp. 2-392, Tropical Health Technology Publications and ButterworthHeinemann Ltd., Cambridge.

Cheesbrough, M., 2009, District laboratory practice in tropical countries, part 2, pp. 62-69, Cambridge University press, Cambridge.

CLSI, 2017, Performance Standards for Antimicrobial Susceptibility Testing, 27th edn CLSI supplement M100, Clinical and Laboratory Standards Institute, Wayne, PA.

CLSI (Clinical and Laboratory Standard Institute), 2008, 'Performance standards for antimicrobial susceptibility testing', in Eighteenth informational supplement: M100-S18, pp. 46-52, vol. 28, Issue 1, Philadelphia, PA.

Cowan, M.M., 1999, 'Plant products as antimicrobial agents', Clinical Microbiology Reviews 12(4), 564-582. https://doi.org/10.1128/CMR.12.4.564

Darwish, R.M., Aburjai, T., Al-Khalil, S., Mahafza, A. \& Al-Abbadi, A., 2002, 'Screening of antibiotic resistant inhibitors from local plant materials against two different strains of Staphylococcus aureus', Journal of Ethnopharmacology 79(3), 359-364. https://doi.org/10.1016/S0378-8741(01)00411-1

Duraipandiyan, V. \& Ayyanar, M., 2006, 'Antimicrobial activity of some ethnomedicinal plants used by Paliyar tribe from Tamil Nadu, India', BMC Complementary and Alternative Medicine 6, 35. https://doi.org/10.1186/1472-6882-6-35

Eloff, J.N., 1998, 'Which extractant should be used for the screening and isolation of antimicrobial components from plants?', Journal of Ethnopharmacology 60(1), 1-8. https://doi.org/10.1016/S0378-8741(97)00123-2

European Committee for Antimicrobial Susceptibility Testing (EUCAST), 2000 'Determination of minimum inhibitory concentrations (MICs) of antibacterial agents by agar dilution', Clinical Microbiology and Infection 6(9), 509-515. https:// doi.org/10.1046/j.1469-0691.2000.00142.x

Fabry, W., Okemo, P.O. \& Ansorg, R., 1998, 'Antibacterial activity of East African medicinal plants', Journal of Ethnopharmacology 60(1), 79-84. https://doi. org/10.1016/S0378-8741(97)00128-1

Falugi, F., Kim, H.K., Missiakas, D.M. \& Schneewind, O., 2013, 'Role of protein A in the evasion of host adaptive immune responses by Staphylococcus aureus', mMBio 4(5), e00575-e13. https://doi.org/10.1128/mBio.00575-13

Fasching, C.E., Peterson, L.R., Moody, J.A., Sinn, L.M. \& Gerding, D.N., 1990, 'Treatment evaluation of experimental staphylococcal infections comparing $\beta$-lactam, lipopeptide, and glycopeptide antimicrobial therapy', Journal of Laboratory and Clinical Medicine 116(5), 697-706.

Gillet, Y., Issartel, B., Vanhems, P., Fournet, J.-C., Lina, G., Bes, M. et al., 2002, 'Association between Staphylococcus aureus strains carrying gene for PantonValentine leukocidin and highly lethal necrotising pneumonia in young immunocompetent patients', Lancet 359(9308), 753-759. https://doi.org/ 10.1016/S0140-6736(02)07877-7 
Govindappa, M., Bharath, N., Shruthi, H.B., Sadananda, T.S. \& Sharanappa, P., 2011 'Antimicrobial, antioxidant and in vitro anti-inflammatory activity and phytochemical screening of Crotalaria pallida Aiton', African Journal of Pharmacy phytochemical screening of Crotalaria pallida Aiton', African Journal of Pharma
and Pharmacology 5(21), 2359-2371. https://doi.org/10.5897/AJPP11.038

Grothe, C., Belasco, A., Bettencourt, A., Diccini, S., Vianna, L., Pignatari, A. et al., 2009, 'Lethality of endocarditis due to Staphylococcus aureus among patients on hemodialysis', Nephrology Nursing Journal 36(6), 613-632.

Khorvash, F., Abdi, F., Ataei, B., Heisiani, H.F., Kashani, H.H. \& Narimani, T., 2012, 'Nasal carriage of Staphylococcus aureus: Frequency and antibiotic resistance in healthy adults', Journal of Research in Medical Sciences 17, S229-S232.

Kim, K.S., Lim, D.J., Yang, H.J., Choi, E.K., Shin, M.H., Ahn, K.S. et al., 2013, 'The multitargeted effects of Chrysanthemum herb extract against Escherichia coli 0157:H7', Phytotherapy Research 27(9), 1398-1406. https://doi.org/10.1002/ptr.4859

Lacey, K.A., Geoghegan, J.A. \& McLoughlin, R.M., 2016, 'Factors in skin infection and their potential as a vaccine antigen', Pathogens 5(1), 22. https://doi.org/10.3390/ pathogens5010022

Lekana-Douki, J.B., Liabagui, S.L.O., Bongui, J.B., Zatra, R., Lebibi, J. \& Tour-Ndouo, F.S. 2011, 'In vitro antiplasmodial activity of crude extracts of Tetrapleura tetrapter and Copaifera religiosa', BMC Research Notes 4, 506. https://doi.org/10.1186/ 1756-0500-4-506

Lewis, K. \& Ausubel, F.M., 2006, 'Prospects of plant derived antibacterials', Nature Biotechnology 24(12), 1504-1507. https://doi.org/10.1038/nbt1206-1504

Meng, J.C., Zhu, Q.X. \& Tan, R.X., 2000, 'New antimicrobial mono- and sesquiterpenes from Soroseris hookeriana subsp. Erysimoides', Planta Medica 66(6), 541-544. https://doi.org/10.1055/s-2000-8607

Moglad, E.H., 2021, 'Loranthus acaciae: Alternative medicine for b-lactamase producer and methicillin-resistant Staphylococcus aureus', Saudi Journal of producer and methicillin-resistant Staphylococcus aureus', Saudi Journal of
Biological Sciences 28(3), 1835-1839. https://doi.org/10.1016/j.sjbs.2020.12.029

Moreillon, P., Que, Y.A. \& Glauser, M.P., 2005, 'Staphylococcus aureus (including Staphylococcal toxic shock)', in G.L. Mandell, J.E. Bennett \& R. Dolin (eds.) Mandell, Douglas and Bennett's principles and practice of infectious diseases, 6 th edn., pp. 2321-2348, Elsevier Churchill Livingstone Publishers, Philadelphia, PA.

Ncube, N.S., Afolayan, A.J. \& Okoh, A., 2008, 'Assessment techniques of antimicrobial properties of natural compounds of plant origin: Current methods and future trends', African Journal of Biotechnology 7(12), 1797-1806. https://doi. org/10.5897/AJB07.613

Nickerson, E.K., West, T.E., Day, N.P. \& Peacock, S.J., 2009, 'Staphylococcus aureus disease and drug resistant in resource-limited countries in South and East Asia', Lancet Infectious Diseases 9(2), 130-135. https://doi.org/10.1016/S14733099(09)70022-2
Note, O.P., Mitaine-Offer, A.C., Miyamoto, T., Paululat, T., Pegnyemb, D.E. \& Lacaille Dubois, M.A. 2009 'Tetrapterosides A and B, two new oleanane-type saponins from Tetrapleura tetraptera', Magnetic Resonance in Chemistry 47(3), 277-282. https://doi.org/10.1002/mrc.2381

Nyenje, M. \& Ndip, R.N., 2011, 'In vitro antimicrobial activity of crude acetone extract of the stem bark of Combretum molle against selected bacterial pathogens', Journal of Medicinal Plants Research 5(21), 5315-5320.

Ojewole, J.A., 2005, 'Analgesic and anticonvulsant properties of Tetrapleura tetraptera (Taub) (Fabaceae) fruit aqueous extract in mice', Phytotherapy Research 19(12), 1023-1029. https://doi.org/10.1002/ptr.1779

Okwu, D.E., 2003, 'The potentials of Ocimum gratissimum, Penrgularia extensa and Tetrapleura tetraptera as spice and flavouring agent', Nigeria Agricultural Journal 34(1), 143-148. https://doi.org/10.4314/naj.v34i1.3184

Olajuyigbe, O.O. \& Afolayan, A.J., 2011, 'In vitro antibacterial activities of the methanol extract of Ziziphus mucronata Willd. Subsp. mucronata Willd', Journal of Medicina Plants Research 5(16), 3791-3795. https://doi.org/10.1186/1472-6882-11-130

Olajuyigbe, O.O. \& Afolayan, A.J., 2012, 'In vitro pharmacological activity of the crude acetone extract of Erythrina caffra Thunb: Antibacterial and antifungal assessment', Journal of Medicinal Plants Research 6(9), 1713-1720. https://doi. org/10.5897/JMPR11.1517

Olajuyigbe, O.O. \& Afolayan, A.J., 2018, 'In vitro antistaphylococcal activity of the ethanolic extract of Tetrapleura tetraptera (Schum and Thonn.) Taub. against methicillin resistant Staphylococcus aureus in urinary tract infections', Kragujevac Journal of Science 40, 193-204. https://doi.org/10.5937/KgJSci18401930

Rios, J.L. \& Recio, M.C., 2005, 'Medicinal plants and antimicrobial activity', Journal of Ethnopharmacology 100(1-2), 80-84. https://doi.org/10.1016/j.jep.2005.04.025

Shanholtzer, C.J., Peterson, L.R., Mohn, M.L., Moody, J.A. \& Gerding, D.N., 1984 'MBCs for Staphylococcus aureus as determined by macrodilution and microdilution techniques', Antimicrobial Agents and Chemotherapy 26(2), 214-219. https://doi.org/10.1128/AAC.26.2.214

Shanmughapriya, S.A., Manilal, A., Sujith, S., Selvin, J., Kiran, G.S. \& Natarajaseenivasan, K. 2008 , 'Antimicrobial activity of seaweeds extracts against multi-resistant pathogens', Annals of Microbiology 58, 535-541. https://doi.org/10.1007/BF03175554

Simões, M., Bennett, R.N. \& Rosa, E.A., 2009, 'Understanding antimicrobial activities of phytochemicals against multidrug resistant bacteria and biofilms', Natural Product Reports 26(6), 746-757. https://doi.org/10.1039/b821648g

Zhang, H.Z.A., 2001, 'Proteolytic transmembrane signaling pathway and resistance to beta lactams in Staphylococci', Science 291(5510), 1962-1965. https://doi. org/10.1126/science.1055144 